\title{
Treatment of Chronic Hepatitis B with Tenofovir Disoproxil Fumarate in Ivory Coast
}

\author{
Ya Henriette Kissi Anzouan-Kacou', Adjeka Stanislas Doffou1, Djeinabou Diallo', \\ Demba Aboubacar Bangoura1, Yacouba Adéhouni2, Hatrydt Dimitri Kouamé1, \\ Alassan Kouamé Mahassadi', Fulgence Yao Bathaix¹, Koffi Alain Attia1, \\ Aya Thérèse Ndri-Yoman 1 \\ ${ }^{1}$ Department of Medicine and Hepatogastroenterology, University Hospital of Yopougon, Abidjan, Côte d'Ivoire \\ ${ }^{2}$ Department of Pharmacy, University Hospital of Yopougon, Abidjan, Côte d'Ivoire \\ Email: kissihy@yahoo.fr
}

Received 3 February 2016; accepted 23 February 2016; published 26 February 2016

Copyright (C) 2016 by authors and Scientific Research Publishing Inc.

This work is licensed under the Creative Commons Attribution International License (CC BY).

http://creativecommons.org/licenses/by/4.0/

(c) (i) Open Access

\section{Abstract}

Little data exist on patients treated with tenofovir in Sub-Saharan Africa. Objective: To describe the clinical and laboratory characteristics of patients with viral hepatitis $B$ treated with tenofovir. Material and methods: A descriptive single-center retrospective study, on chronic viral hepatitis B mono-infected, followed in the hepatogastroenterology department of the University Hospital of Yopougon and treated with tenofovir from February 2012 to February 2015. The studied parameters were demographic, clinical, biochemical, serological, virological, abdominal ultrasound. Liver fibrosis was assessed either by liver biopsy or non-invasive tests. Results: 110 patients were treated with tenofovir disoproxil fumarate with a mean age of 40.4 years and a male predo- minance. Clinical examination revealed jaundice in $9 \%$ of cases, hepatomegaly in $7.3 \%$ of cases, splenomegaly in $9.1 \%$ of cases and ascites in $15.5 \%$ of cases. The AST averaged $77.3 \mathrm{IU} / \mathrm{l}$, the ALT 76.8 $\mathrm{IU} / \mathrm{l}$, prothrombin rate at $76.6 \%$, albumin level at $32.3 \mathrm{~g} / \mathrm{l}$, total bilirubin at $29.9 \mathrm{~g} / \mathrm{l}$, alpha fetoprotein rate at $15.3 \mathrm{ng} / \mathrm{ml}$. HBe antigen was negative in $76.2 \%$ of cases. The average rate of DNA at baseline was $7.4 \log 10 \mathrm{IU} / \mathrm{l} .27 .5 \%$ was cirrhotic. The average time of starting treatment was 23.7 months. Conclusion: TDF is the first-line treatment for chronic hepatitis B in our country, because it is a well-tolerated, potent therapy with a high threshold for resistance development. Our study population had an average age of 40.4 years. Virological profile was dominated by HBe antigen negative patients and high viral load of HVB DNA. One third of patients were at the stage of cirrhosis. This treatment must be delivered free of charge in all the country hospitals, which is going to improve significantly the natural evolution of the disease and to decrease the incidence of the HCC. 


\section{Keywords}

\section{Chronic Hepatitis B Virus, Tenofovir Disoproxil Fumarate, Treatment, Ivory Coast, Sub-Saharan Africa}

\section{Introduction}

Viral hepatitis B is highly endemic in Sub-Saharan Africa, where more than $8 \%$ of the populations are chronic carriers [1]-[4]. In the Ivory Coast, several studies suggest a prevalence of HBs antigen ranging from $10 \%$ to $17 \%$ depending on the study population [5]-[8]. In our countries, the contamination is made most of the time during perinatal period (vertical transmission) and the early childhood (horizontal transmission). The blood way is also high because of the traditional practices of scarifications, circumcisions and tattoos where the measures of hygiene are not still respected. The risks in the blood transfusion are small in our country because of the transfusional security measures [6] [7]. $20 \%$ to $40 \%$ of patients with chronic hepatitis B may progress to liver cirrhosis and its complications [1] [9]-[11]. The treatment of Viral Hepatitis B (VHB) aims to suppress DNA replication of hepatitis B virus (HBV), reduce necroinflammation, prevent progressive fibrosis, and finally eliminate hepatitis B virus (HBV) [1] [9]-[11]. WHO in its guidelines for hepatitis B in 2015, recommends to prioritize antiviral treatment to those with established cirrhosis (based on non-invasive measurements of fibrosis), clinical evidence of decompensated liver disease, or evidence of chronic active hepatitis indicated by abnormal transaminases and high load of HBV DNA (above 20,000 IU/ml) [1]. Currently, several drugs are recommended for the treatment of patients with chronic HBV [1] [2] [10] [12], which can be divided into two main groups based on their mechanism of action: immunomodulatory drugs (such as interferon alpha) and antiviral medicines including lamivudine, telbivudine, entecavir, tenofovir disoproxil fumarate (TDF) [1] [10] [12]. TDF is effective against mutant or wild-type of virus and HBV lamivudine-resistant [10] [12] [13], or in case of decompensated cirrhosis [10] [14]. No TDF resistance was detected so far [11] [13]. In developing countries with high endemicity, access to antiviral therapy is still very limited because TDF is available and free of charge for individuals coinfected with HIV and not for mono infected individuals. There is a lot to do regarding the diagnosis and management of chronic HBV in populations without HIV [3] [15]. Access to diagnosis and treatment of chronic hepatitis B remains a challenge in the Ivory Coast where available drugs are pegylated interferon, lamuvidine and TDF which are not free of charge. There are limited data on patients treated with TDF in Sub-Saharan Africa. The purpose of the work is to describe the clinical and biological features in clinical practice of HVB mono infections treated with TDF in a consultation department of hepatogastroenterology in a high endemic area of HVB.

\section{Material and Methods}

This is a descriptive retrospective study on patients followed in the hepatogastroenterology department at the University Hospital in Yopougon, from February 2012 to February 2015 and treated with TDF for an indefinite period: it was about the fumarate of tenofovir disoproxil (Tenvir ${ }^{\circledR}$ of Cipla) delivered free of charge in the 3 Teaching Hospitals of Abidjan thanks to the National Program of Fight against the Viral Hepatitis (NPFVH). TDF was given at the $300 \mathrm{mg}$ daily dose, the only dosage available in hospitals, which was also used for the coinfected patient's HVB + HIV. Inclusion criteria were: chronic active VHB (HBs antigen positive for more than 6 months, intermittent or persistent elevated transaminases, HBV DNA $\geq 2000 \mathrm{IU} / \mathrm{ml}$ for HBe antigen negative or $\geq 20,000 \mathrm{IU} / \mathrm{ml}$ for $\mathrm{HBe}$ antigen positive and necroinflammation or a moderate to severe fibrosis), absence of HCV, HDV or HIV coinfection, treatment with tenofovir. Patients with HDV, HCV or HIV coinfection, chronic inactive viral hepatitis B, HVB untreated or treated with another molecule were excluded. The following parameters were investigated: demographic (age, gender), clinical, biochemical (transaminases), serum (antigen HBs, total anti-HBc antibody, antigen HBe, anti-HBe antibody), virological (HBV DNA quantitative by PCR). All patients had had an abdominal ultrasound in search of portal hypertension signs or cirrhosis or HCC. Patients at the stage of cirrhosis had had an upper gastrointestinal endoscopy in search of portal hypertension signs and the determination of alpha fetoprotein in search of HCC.

The detection of the antigen HBs was made according to the sandwich ELISA technique. HBe antigen, an- 
ti-HBe antibodies, anti-HCV antibodies were detected by ELISA test (Biomérieux Clinical Diagnostics, Geneva, Switzerland). HBV DNA was measured by the technique COBAS Ampliprep/COBASTaqMan HBV Version 2.0 from Roche (Meylan, France) with a positive threshold of $20 \mathrm{IU} / \mathrm{ml}$ (linearity from $20 \mathrm{IU} / \mathrm{ml}$ to 170,000,000 $\mathrm{IU} / \mathrm{ml})$. The COBAS TaqMan HBV test (CTM HBV test; Roche Diagnostics, Meylan, France) is a commercial nucleic acid amplification test for HBV DNA viral load determination based on TaqMan PCR chemistry. Clinical samples are loaded into the instrument, which then automatically releases nucleic acids using ready-to-use reagents. Liver fibrosis assessed by liver biopsy, when it was accepted by the patients after informed consent, was made by echo guided sub-costal trans-parietal way under local anesthetic in Xylocaïne ${ }^{\circledR} 1 \%$ by an hepatologist and a radiologist in day hospitalization. Most patients preferred non-invasive methods (Fibrotest ${ }^{\circledR}$-Actitest Biopredictive or Fibrometer ${ }^{\mathbb{B}}$ BioLiveScale or FibroScan ${ }^{\circledR}$ VTME V). When the biopsy was available, data were compiled according to the METAVIR scoring system: A0 for absence of activity A1 for minimal activity A2 for moderate and A3 for severe; F0 for absence of fibrosis, F1 for portal fibrosis without septa, F2 for fibrosis with rare septa, F3 for fibrosis with many septa and F4 for cirrhosis.

\subsection{Ethical Approval}

The analysis was conducted on anonymized data, collected as part of routine patient care. No additional investigations were performed. Therefore, no prior informed consent from the patients was required.

\subsection{Statistical Analysis}

Data were processed using Microsoft Excel 2010 software (Microsoft, Seattle, WA, USA). The description of the sample consisted of calculations of proportions for qualitative variables and averages with their standard deviation for quantitative variables.

\section{Results}

During the study period 3274 patients were received in hepatogastroenterology consultation. There were 516 cases of viral hepatitis (15.7\%) including 414 cases of VHB (80.2\%) and 102 cases of VHC (19.8\%). 110 patients $(26.6 \%)$ VHB were put on treatment with tenofovir. Patients had a mean age of $40.4 \pm 12.1$ years, with extremes ranging from 16 to 77 years. The age group from 40 to 50 years predominated $28.2 \%(\mathrm{n}=31)$, followed by 30 to 40 years $22.7 \%(\mathrm{n}=25)$, from 20 to 30 years $20.9 \%(\mathrm{n}=23), 50$ to 60 years $19.1 \%(\mathrm{n}=21)$. There was a male predominance of 83 men $(75.5 \%)$ for 27 women $(24.5 \%)$ with a sex ratio of $3.1 .5 .4 \%$ had received prior treatment with pegylated interferon; one patient was already on tenofovir and $93.6 \%$ were treatment-naive. The average time of starting treatment was 23.7 months $(1-232)$ compared to the date of diagnosis. The clinical examination was normal in most cases. However patients presented jaundice in $10 \%$ of cases, hepatomegaly in $7.3 \%$ of cases, splenomegaly in $9.1 \%$ of cases and ascites in $15.5 \%$ of cases. This was decompensated cirrhosis.

Demographic and clinical characteristics of the patients are summarized in Table 1.

Regarding the liver function test results, AST averaged $77.3 \pm 88.7$ IU/1 (10 - 697), ALT $76.8 \pm 76$ IU/1 (10 477), prothrombin $76.6 \% \pm 15.1 \%$ (11 - 100), albumin $32.3 \pm 9.6 \mathrm{~g} / \mathrm{l}(17-47)$, total bilirubin $29.9 \pm 47.5 \mathrm{~g} / \mathrm{l}(2.1$ - 278), the level of alpha fetoprotein $15.36 \pm 43 \mathrm{ng} / \mathrm{ml}(2.1-229.55)$. HBe antigen was negative in $76.2 \%$. The

Table 1. Demographic and clinical characteristics of patients.

\begin{tabular}{cc}
\hline Parameters (unit) & Value \\
\hline Age (years) & $40.3 \pm 12.2$ \\
Sex ratio & 3.1 \\
Jaundice (\%) & 10 \\
Hepatomegaly (\%) & 7.3 \\
Splenomegaly (\%) & 9.1 \\
Ascite (\%) & 15.5 \\
Naive (\%) & 94.5 \\
Treatment delay (months) & 23.7 \\
\hline
\end{tabular}


average rate of DNA at baseline was $26,712,099.66 \pm 50,401,405.68 \mathrm{IU} / \mathrm{ml}(41-170,000,000)$, i.e. $7.4 \log 10$ $\mathrm{IU} / \mathrm{ml} \pm 7.7 \log 10 \mathrm{IU} / \mathrm{ml}$. Abdominal ultrasound showed 30 cases of liver cirrhosis (27.3\%) 17 of which were at the stage of decompensation with ascites $(15.45 \%)$. There were 2 cases of suspected nodules of HCC on CT scan with a nodule of $12 \times 10 \mathrm{~mm}$ and 2 nodules whose size were not specified. Moreover abdominal ultrasound showed one homogenous hepatomegaly in 12 cases (10.9\%), 1 case of liver atrophy, 12 cases (10.9\%) of splenomegaly, 3 cases of fatty liver disease, 3 cases of gallstones, 2 cases of hepatic hemangioma. To assess the histology, we performed 9 liver biopsies, 44 fibrotests, 12 fibroscans and 4 fibrometers. The activity was greater or equal to 2 in 4/9 liver biopsies, 15/44 fibrotests, 3/4 fibrometers. Fibrosis was greater or equal to 2 in 7/9 liver biopsies, 33/44 fibrotests, 6/12 fibroscans and 4/4 fibrometers. Patients were at the stage F4 of cirrhosis in 2/9 cases of liver biopsies, 10/44 cases of fibrotests, $3 / 12$ cases of fibroscan and 4/4 cases of fibrometers. Upper gastrointestinal endoscopy performed in 23 patients with cirrhosis showed esophageal varices in 13 cases (56.5\%), which were grade 1 in 6 cases, grade 2 in 6 cases and grade 3 in 1 case.

Laboratory characteristics of the patients are summarized in Table 2.

\section{Discussion}

Most of what is known about VHB in Africans was drawn from the extrapolation of studies carried out in Western countries and Asia [2]. This is the first study to provide clinical and laboratory features of viral hepatitis B treated with tenofovir at the institution of the treatment in the Ivory Coast. Even if it's retrospective nature and incomplete data limit the study, its major strength is that it was carried out in the Ivory Coast, where chronic infection with hepatitis B is endemic. In our daily practice, chronic hepatitis B raises a management problem, due to late diagnosis of the disease and its complications such as cirrhosis and HCC and the lack of resources for monitoring, on the one hand from the side of patients (lack of money) and on the other hand from the side of hospitals (lack of equipment and medicines) [16].

Our patients had an average age of $40.3 \pm 12.2$ years as well as patients in Burkina Faso (40 years) [17] while in Iran the average age was $38 \pm 12$ years [18]. In Turkey treated patients were older at $45.34 \pm 14.19$ years [14], in Greece $46.9 \pm 10.7$ years [19]. Korea had the highest average age 51 years [20]. One study showed that patients without cirrhosis were younger than cirrhotic patients with a mean age of 38.4 years and 45.2 years with a significant difference [21]. Male predominance of our patients (75.5\%) was found in all other studies to $67.7 \%$ [14], 77\% [18], 82.5\% [17], 63\% [20], 54\% [19] whether patients were HBe antigen positive or HBe antigen negative $80.9 \%$ and $71.6 \%$ [22], and $61.1 \%$ and $74.5 \%$ [23], cirrhotic or non-cirrhotic to $81 \%$ and $72 \%$, respectively [21].

The frequency of HBe antigen-negative patients has increased over the past decade as a result of an aging population with HBV and represents the majority of cases in some regions, including Europe [1] [24]. Asia is an exception with predominance of HBe antigen positive [25]. Chronic hepatitis B with HBe antigen negative is associated with a low rate of spontaneous remission. Patients are at risk of developing in the long-term severe fibrosis, cirrhosis and HCC [9]. Therefore early diagnosis and treatment of chronic hepatitis B are crucial to reduce morbidity and mortality [22]. According to the literature, the results of our study show a clear predominance of $\mathrm{HBe}$ antigen $75.3 \%$ of patients as well as other studies whose number of $\mathrm{HBe} \mathrm{Ag}$-negative patients was $64.5 \%$ [18], 69\% [17], whether patients are at the stage of cirrhosis (61\%) or not (59\%) [20].

Table 2. Laboratory characteristics of the patients.

\begin{tabular}{cc}
\hline Parameters (unit) & Value \\
\hline HBe antigen negative $(\%)$ & 76.3 \\
DNA VHB (log10 UI/ml) & $7.4 \pm 7.7$ \\
AST (UI/L) & $77.3 \pm 88.7$ \\
ALT (UI/L) & $76.8 \pm 76$ \\
Prothrombin (\%) & $76.6 \pm 15.2$ \\
Albumin (g/l) & $32.3 \pm 9.6$ \\
Total bilirubin $(\mathrm{mg} / \mathrm{l})$ & $29.9 \pm 47.5$ \\
Alpha fetoprotein $(\mathrm{ng} / \mathrm{ml})$ & $15.4 \pm 43$ \\
F4 (\%) & 27.5 \\
\hline
\end{tabular}


Three criteria are essential to establish the indication of treatment: serum level of ALT, serum level of HBV DNA and severity of liver disease [9]. Treatment should be considered if the HBV DNA level is higher than $2000 \mathrm{IU} / \mathrm{ml}$, if the ALT level is higher than the upper limit of normal and if the severity of liver disease, as assessed by a liver biopsy shows an activity from moderate to severe $(\mathrm{A} \geq 2)$, and/or mild fibrosis $(\mathrm{F} \geq 2)$ (METAVIR score). If patients meet these criteria for HBV DNA levels and the severity of histological lesions, the treatment may be started even if the ALT levels are normal [9]. Our patients met these criteria with ALT levels at baseline that averaged $76.8 \pm 76 \mathrm{IU} / 1$, not different from the Iranian data $73 \pm 54 \mathrm{IU} / 1$ [18] but was lower than European data whose average rate of ALT was 103.52 $\pm 126.67 \mathrm{IU} / 1$ [14], $115 \pm 124 \mathrm{IU} / 1$ [19] or Asian $126.3 \mathrm{IU} / 1$ [20] $143.2 \pm 123.4 \mathrm{IU} / 1$ in cirrhotic patients and $143 \pm 113.1 \mathrm{IU} / 1$ in non-cirrhotic patients [21]. In Brazil ALT levels were as high at 109.0 and 145.5 [23].

Our patients had a mean viral load of $7.4 \pm 7.7 \log 10 \mathrm{IU} / \mathrm{ml}$, which is high compared to the average viral load of Sombié and al who found a viral load 10 times lower $(221,000 \mathrm{IU} / \mathrm{ml})$ [17] or western data 1,100,000 IU/ml [14], $6.8 \log 10 \mathrm{IU} / \mathrm{ml}$ for cirrhotic patients and $6.9 \log 10 \mathrm{IU} / \mathrm{ml}$ for non-cirrhotic patients [22]. A study showed that patients with a high viral load take a longer time to reach HBV DNA levels undetectable compared to patients with low viral loads [4]. We expect that our patients will take a long time to reach HBV DNA levels undetectable.

The identification of people in advanced stages of chronic HBV or at the stage of cirrhosis in the indication of treatment is usually based on a combined assessment of clinical signs (including hepatomegaly and splenomegaly), the level and ratio of aminotransferase and other relevant tests, such as albumin and platelet counts, viral load, the degree of fibrosis and/or necroinflammation on liver biopsy or non invasive tests and imaging of the liver [1]. From a clinical perspective our patients presented a picture of decompensated cirrhosis with ascites in $15.5 \%$ of cases, jaundice in $10 \%$ of cases, hepatomegaly in $7.3 \%$ of cases and splenomegaly in $9.1 \%$ of cases. The ultrasound showed cirrhosis in $27.7 \%$ of cases. Most people are unaware of their HBV infection and therefore are often received in consultation in advanced stage of the disease [1].

Liver biopsy is considered as the gold standard for assessing the stage of liver disease and the degree of fibrosis, but it is not widely used in countries with limited resources because of its high cost, its invasive character, the risk of complications and sampling error, as well as the need for an expert histological interpretation [1]. Several non-invasive blood fibrosis tests $\left(\right.$ Actitest $^{\mathbb{B}}$-Fibrotest ${ }^{\mathbb{R}}$, Inflameter ${ }^{\mathbb{B}}$ Fibrometer ${ }^{\mathbb{B}}$ ) or ultrasound (FibroS$\mathrm{can}^{B}$ ) are now available and increasingly used to assess liver fibrosis, reducing the indication of liver biopsy in the people with chronic liver disease [1]. The recommendations promote the use of simple non-invasive diagnostic tests, to assess liver disease and eligibility to treatment [1]. As the diagnosis of HBV HBe antigen negative usually occurs at the stage of advanced disease, it is not surprising that significant inflammatory changes and fibrosis occur in more than 50\% of HBe negative patients with $25 \%-50 \%$ presenting cirrhosis at diagnosis [11]. Almost $1 / 3$ of our patients were at the stage of cirrhosis whether at the ultrasound or fibrosis tests, which shows that our patients are diagnosed at an advanced stage of the disease. In Brazil, cirrhosis was present in $33.9 \%$ of $\mathrm{HBe}$ antigen-positive patients and in $16.3 \%$ of HBe antigen negative patients [23]. In a multicenter study $24.0 \%$ had cirrhosis at baseline [22]. In the Korean study $51 \%$ of patients were at the stage of cirrhosis [20] in Turkey 3.7\% were at the stage of liver cirrhosis before treatment with tenofovir [14], cirrhosis was present in 9\% Iranian patients [18]. As the diagnosis of negative HVB antigen $\mathrm{HBe}$ is usually made at the evolved stage in the disease, it is not surprising that significant inflammatory changes and the fibrosis are present in more than $50 \%$ of negative patients $\mathrm{HBe}$, with $25 \%-50 \%$ having the cirrhosis at the time of the diagnosis [11].The long-term antiviral therapy in clinical practice can lead to regression of fibrosis and liver architectural improvement of $\mathrm{HBe} \mathrm{Ag}$ negative patients. Thus, histological improvement could be a reasonable criterion of treatment [19]. TDF is effective in VHB naive patients as well as in multi-resistant patients, both HBe antigen positive and HBe antigen negative [11]. $93.6 \%$ of our patients were naive of any previous treatment, because of the difficulty getting the treatment in our center. In our study, 6 patients already had a previous treatment: 5 were put under pegylated Interferon replaced by the TDF after the failure of the treatment and 1 patient was already under the TDF which he had got himself in another center. We did not identify a patient put under lamuvidine in our cohort. In other studies $13.2 \%$ negative antigen $\mathrm{HBe}$ and $11.4 \%$ positive antigen $\mathrm{HBe}$ had already set of the previous lamivudine or experienced Interferon previously $17.8 \%$ and $16.4 \%$ respectively without significant difference [22]. 52.4\% were naive of any treatment and $46.9 \%$ had already received a treatment (standard interferon, pegylated Interferon, lamuvidine, entecavir, adefovir) [14].

The average deadline of our patients' treatment was of 23.7 months which is very long. It is due to the fact 
that the majority of our patients are not insured and of socioeconomic low level, they experienced difficulties realizing a complete balance sheet assessment of the disease before the putting under treatment. TDF was delivered free of charge during our period of study what was not still the case, those who had been diagnosed before 2012 had difficulty getting themselves the treatment. The costs of screening, the follow-up and the treatment are responsible for the low diagnostic rate of HBV in Asia, but also for the low rate of treatment among diagnosed patients (4\% in Korea against $20 \%$ in the USA, $17 \%-28 \%$ in Europe and $8 \%$ in Japan). These opposite figures reflect the difference in the level of development or the income of countries and indicate so clearly that the lack of economic resources is the main obstacle for the appropriate management of HBV in Asia [20]. Sub-Saharan Africa and in particular Ivory Coast is in the same situation.

\section{Conclusion}

TDF is the first-line treatment for chronic hepatitis B in our country, because it is a well-tolerated, potent therapy with a high threshold for resistance development. Our study population had an average age of 40.4 years with a male predominance. Virological profile was dominated by HBe antigen negative patients and high viral load of HVB DNA. One third of patients were at the stage of cirrhosis and the average delay before starting treatment was long. This treatment must be delivered free of charge in all the country hospitals, which is going to improve significantly the natural evolution of the disease and to decrease the incidence of the HCC.

\section{Conflict of Interests}

The authors declare that there is no conflict of interest regarding the publication of this paper.

\section{References}

[1] World Health Organisation (2015) Guidelines for the Prevention, Care and Treatment of Persons with Chronic Hepatitis B Infection.

[2] Nwokediuko, S.C. (2011) Chronic Hepatitis B: Management Challenges in Resource-Poor Countries. Hepatitis Monthly, 11, 786-793. http://dx.doi.org/10.5812/kowsar.1735143x.757

[3] Stockdale, A.J. and Geretti, A.M. (2015) Chronic Hepatitis B Infection in Sub-Saharan Africa: A Grave Challenge and a Great Hope. Transactions of the Royal Society of Tropical Medicine and Hygiene, 109, 421-422. http://dx.doi.org/10.1093/trstmh/trv044

[4] Edmunds, G.F., Medley, W.J., Nokes, D.J., O’Callaghan, C.J., Whittle, H.C. and Hall, A.J. (1996) Epidemiological Patterns of Hepatitis B Virus (HBV) in Highly Endemic Areas. Epidemiology and Infection, 117, 313-325. http://dx.doi.org/10.1017/S0950268800001497

[5] Assi, C., Allah-Kouadio, E., Ouattara, A., Diakité, M., Koné, S., Lohoues-Kouacou, M.J. and Camara, B.M. (2011) Couverture vaccinale contre l'hépatite virale $\mathrm{B}$ et prévalence de l'antigène HBs dans une profession à risque : Etude transversale portant sur 244 sapeurs-pompiers de la ville d'Abidjan. Journal Africain d'Hépato-Gastroentérologie, 5 , 115-118. http://dx.doi.org/10.1007/s12157-011-0262-6

[6] Kouassi-M'bengue, A., Cissé, B., Ouattara, D.N., Doumbia, M., Yao, H., Gnonsahé, D. and Dosso, M. (2011) Fréquences de l'hépatite virale B et du VIH Chez Les Hémodialysés à Abidjan en 2010. Revue Bio-Africa, 11, 43-48.

[7] Kra, O., N'Dri, N., Ehui, E., Ouattara, B. and Bissagnene, E. (2007) Prévalence de l'antigène HBs chez les donneurs de sang au centre régional de transfusion sanguine de Bouaké (Côte d'Ivoire) en 2001. Bulletin de la Societe de Pathologie Exotique, 100, 127-129.

[8] Kra, O., N’Dri, N., Koné, D., Kadiané, N.J., Aba, Y.T., Ouattara, B. and Bissagnéné, E. (2015) Prevalence of HBs Antigen Carriage in a Population of Recruits of the National Gendarmerie of Ivory Coast in 2010. African Journal of Infectious Diseases Research, 2, 80-83.

[9] EASL: European Association for the Study of the Liver (2012) Clinical Practice Guidelines: Management of Chronic Hepatitis B Virus Infection. Journal of Hepatology, 57, 167-185. http://dx.doi.org/10.1016/j.jhep.2012.02.010

[10] Liaw, Y.-F., Kao, J.-H., Piratvisuth, T., Chan, H.L.Y., Chien, R.-N., Liu, C.-J., Gane, E., Locarnini, S., Lim, S.-G., Han, K.-H., Amarapurkar, D., Cooksley, G., Jafri, W., Mohamed, R., Hou, J.-L., Chuang, W.-L., Lesmana, L.A., Sollano, J.D., Suh, D.-J. and Omata, M. (2012) Asian-Pacific Consensus Statement on the Management of Chronic Hepatitis B: A 2012 Update. Hepatology International, 6, 531-561. http://dx.doi.org/10.1007/s12072-012-9365-4

[11] (2014) Sous la direction du Pr Daniel Dhumeaux et sous l'égide de l'ANRS et de l'AFEF. Prise en Charge des Personnes Infectées par Les Virus de l'Hépatite B ou de l'Hépatite C, Rapport de Recommandations 2014. 
[12] Zhao, S.-S., Tang, L.-H., Dai, X.-H., Wang, W., Zhou, R.-R., Chen, L.-Z. and Fan, X.-G. (2011) Comparison of the Efficacy of Tenofovir and Adefovir in the Treatment of Chronic Hepatitis B: A Systematic Review. Virology Journal, 8, 111. http://dx.doi.org/10.1186/1743-422X-8-111

[13] Heathcote, E.J., Marcellin, P., Buti, M., Gane, E., De Man, R.A., Krastev, Z., Germanidis, G., Lee, S.S., Flisiak, R., Kaita, K., Manns, M., Kotzev, I., Tchernev, K., Buggisch, P., Weilert, F., Kurdas, O.O., Shiffman, M.L., Trinh, H., Gurel, S., Snow-Lampart, A., Borroto-Esoda, K., Mondou, E., Anderson, J., Sorbel, J. and Rousseau, F. (2011) Three-Year Efficacy and Safety of Tenofovir Disoproxil Fumarate Treatment for Chronic Hepatitis B. Gastroenterology, 140, 132-143. http://dx.doi.org/10.1053/j.gastro.2010.10.011

[14] Örmeci, N., Özbaş, B., Güner, R., Özkan, H., Yalçi, A., Çoban, Ş., Dökmeci, A., Kalkan, Ç., Akınc1, H., Yüksel, O., Başar, Ö., Yüksel, I. and Balik, I. (2015) Tenofovir-Best Hope for Treatment of Chronic Hepatitis B Infection? The Turkish Journal of Gastroenterology, 26, 322-327.

[15] Lemoine, M., Nayagam, S. and Thursz, M. (2013) Viral Hepatitis in Resource-Limited Countries and Access to Antiviral Therapies: Current and Future Challenges. Future Virology, 8, 371-380. http://dx.doi.org/10.2217/fvl.13.11

[16] Sombié, R., Bougouma, A., Diallo, O., Bonkoungou, G., Cissé, R., Sangare, L., Sia, R., Serme, K. and Ilboudo, D. (2010) Hépatite B chronique: Aspects épidémiologique, diagnostique, thérapeutique et évolutif au Centre Hospitalier Universitaire Yalgado Ouédraogo de Ouagadougou. Journal Africain d'Hépato-Gastroentérologie, 4, 3-10. http://dx.doi.org/10.1007/s12157-009-0137-2

[17] Sombié, R., Sangaré, L., Guingané, A., Tiendrébéogo, A., Kaboré, D. and Bougouma, A. (2015) Traitement de l'hépatite B chronique par les analogues de nucléos(t)ides. Journal Africain d'Hépato-Gastroentérologie, 9, 114-118. http://dx.doi.org/10.1007/s12157-015-0601-4

[18] Bakhshizadeh, F., Hekmat, S., Keshvari, M., Alavian, S.M., Mostafavi, E., Keivani, H., Doosti, A., Motevalli, F. and Behnava, B. (2015) Efficacy of Tenofovir Disoproxil Fumarate Therapy in Nucleoside-Analogue Naive Iranian Patients Treated for Chronic Hepatitis B. Hepatitis Monthly, 15, Article ID: e25749. http://dx.doi.org/10.5812/hepatmon.15(5)2015.25749

[19] Papachrysosa, N., Hytirogloub, P., Papalavrentiosa, L., Sinakosa, E., Kouvelisa, L. and Akriviadisa, E. (2015) Antiviral Therapy Leads to Histological Improvement of HBe Ag-Negative Chronic Hepatitis B Patients. Annals of Gastroenterology, 28, 372-376.

[20] Ahn, S.S., Chon, Y.E., Kim, B.K., Kim, S.U., Kim, D.Y., Ahn, S.H., Han, K.-H. and Park, J.Y. (2014) Tenofovir Disoproxil Fumarate Monotherapy for Nucleos(t)ide-Naive Chronic Hepatitis B Patients in Korea: Data from the Clinical Practice Setting in a Single Center Cohort. Clinical and Molecular Hepatology, 20, 261-266. http://dx.doi.org/10.3350/cmh.2014.20.3.261

[21] Kim, W.R., Loomba, T., Berg, R., Schall, R.E.A., Yee, L.J., Dinh, P.V., Flaherty, J.F., Martins, E.B., Therneau, T.M., Jacobson, I., Fung, S., Gurel, S., Buti, M. and Marcellin, P. (2015) Impact of Long-Term Tenofovir Disoproxil Fumarate on Incidence of Hepatocellular Carcinoma in Patients with Chronic Hepatitis B. Cancer, 15, 3631-3638.

[22] Buti, M., Fung, S., Gane, E., Afdhal, N.H., Flisiak, R., Gurel, S., Flaherty, J.F., Martins, E.B., Yee, L.J., Dinh, P., Bornstein, J.D., Subramanian, G.M., Janssen, H.L.A., George, J. and Marcellin, P. (2015) Long-Term Clinical Outcomes in Cirrhotic Chronic Hepatitis B Patients Treated with Tenofovir Disoproxil Fumarate for up to 5 Years. Hepatology International, 9, 243-250. http://dx.doi.org/10.1007/s12072-015-9614-4

[23] Chachá, S.G.F., da Costa Ferreira, S., Costa, T.V., de Almeida Filho, L.C., Villanova, M.G., Souza, F.F., Teixeira, A.C., Figueiredo, J.F.C., Zucoloto, S., Ramalho, L.N., da Costa Passos, A.D. and Martinelli, A.L.C. (2011) Clinical, Demographic and Epidemiological Characteristics of Patients with Hepatitis B Followed at a University Hospital in South Eastern Brazil: Predominance of HBe Ag Negative Cases. Revista da Sociedade Brasileira de Medicina Tropical, 44, 13-17. http://dx.doi.org/10.1590/S0037-86822011000100004

[24] Ankouane, F., Kowo, M., Njoya, O., Sida, M.B., Tzeuton, C. and Ndam, E.C.N. (2015) Hépatite B Chronique à Antigène HBe Négatif à Yaoundé, Cameroun. Health Sciences and Disease, 16, 1-5.

[25] Choi, M.S., Sinn, D.H., Kim, S.-A., Lee, Y.S., Choi, W. and Paik, S.W. (2012) The Clinical and Laboratory Characteristics of Patients with Chronic Hepatitis B Using Current or Past Antiviral Therapy in Korea: A Multi-Center, Nation-Wide, Cross-Sectional Epidemiologic Study. Gut and Liver, 6, 241-248. http://dx.doi.org/10.5009/gnl.2012.6.2.241 